\title{
The contribution of headmaster's personality competence to the teacher's social competence of vocational high school
}

\author{
Nellitawati Nellitawati ${ }^{*}$ \\ Universitas Negeri Padang-West Sumatra-Indonesian \\ *) Corresponding author, $\doteq$ e-mail: nellitawati@gmail.com
}

\begin{abstract}
This research aims to know the contribution of headmaster's personality competence to the teacher's social competence at Vocational High School. The type of this research is Correlation. With 55 teachers at the State of Vocational High School in Padang Municipality through sampling technique of stratified random sampling. The used of the instrument is scale of KKPS and KSG. Test Instrument covers testing validity and reliability. The analysis of data uses correlation. The result of this research are: (1) headmaster's personality competence teacher of the State of Vocational High School 6 in Padang Municipality is well, with the level of achievement score 86,2\%, (2) Teacher's Social Competence at the State of Vocational High School 6 in Padang Municipality placed in well category, with the score level achievement $84,97 \%$, (3) There is a well correlation between headmaster's personality competence with teacher's social competence at the State of Vocational High School 6 in Padang Municipality with coefficient correlation $r_{\text {count }}=0,36>$ $\mathrm{r}_{\text {table }}=0,207$ in level of credibility $95 \%$. The level of headmaster's personality competence is relative minor to the teacher's social competence at the State of Vocational High School 6 in Padang. It means that headmaster's personality competence gives the contribution to the teacher's social competence at the State of Vocational High School 6 in Padang Municipality is around $12,96 \%$.
\end{abstract}

\section{Keywords: Personality Competence, Social Competence}

How to Cite: Nellitawati. (2017). The contribution of Headmaster's Personality Competence to the Teacher's Social Competence of Vocational High School. Couns-Edu: International Journal of Counseling and Education, 2 (1): pp. 25-34. DOI: 10.23916/002017027710

\section{Introduction}

Vocational High School is a part of formal educational institution Which became parts of education (Indonesia, P. R, 2003). One of the goal of Vocational High School tends to the development of student's skill on doing a certain work (Indriyanti, \& Ivada, 2013; Purnomo, E., \& Munadi, S. 2005; Arnawa, I. K. 2012; Yasin, M., \& Ansori, A 2014), beside that Vocational High School is also to prepare the students enter the work field and it can also increase professional of student. (Adiputra, I. N., Sugihartini, N., Wahyuni, D. S., \& Sunarya I. M. G. 2014). So in line with this, it needs a good and positive school environment, and also it does not far from the headmaster's personality, teachers, and family's school. A good personality has a strong effect to the school situation and class room atmosphere, teachers who has good personality can be able to give the students an autonomy to show their thought and increase their creativity and personality (Surya, H., 2010; Yuniarti, Y., Harsono, N., \& Istiani, T. 2015). Teacher's 


\section{COUNS-EDU}

Vol. 2, No.1, March 2017

Available online: http://journal.konselor.or.id/index.php/counsedu

Nellitawati ,N

personality is the same with individual personality as usual consist with physical aspects, intellectual, social, emotional and moral (Fitriani, L. 2012; Masruroh, N. 2010). All of the aspects have the relation each others, not only personality but also teacher's social competence is really needed.

The successful implementation of education and teaching in schools takes on the role of teachers. Teachers are one of the factors of success of teaching and learning process (Ariyanti S, 2008). Basically, teacher is guidance of students in order to enhance student's potential and reach the goal of education. Teaching learning process cannot be run well if the teacher can not to communicate to the students well. It is not only in the school environment but also a part of society, he or she should be known to ensure socialization to the society (Munawaroh, D. 2014; Maghfiroh, A. 2010; Muspiroh, N. 2016). Teacher is the resource of management which has face to face contact with the students that should be capable to held his job as the educator and good teacher. At the low of Indonesian Republic No.14 year 2015 section (10) about teacher and lecture, said that teacher's competences are; pedagogical, professional, social, and personal competence.

Teacher should be known about how to make communications in order to ensure the process of teaching learning ran well, not only in the school environment but also teacher should make communications and also keeping a good relation with the society (Avalos, B. 2011). Teacher should be able to communicate with the students, society, and parent of the students. A teacher's frame becomes a figure to the students through seeking to the personality and soul of their teacher (Putri, N. A, 2011; Mala, D. K. 2016).

In this case the demands of the teacher not only to draw the lesson (Sharples, M. 2002; Wong, J. K. K. 2004) but the important thing is how the teacher makes the lesson becomes the area of building competition and recharge to the personal quality and soul of the students (Yuni, R. 2015). Teacher is always became the figured by the society (Munawaroh, D. 2014; Syikhul Alim, M. 2010; Muspiroh, N. 2016; Ariansyah, B. 2016), that is why the teacher needs to know the values existing in the society in his local job. Beside that personality and the way teacher's talk determine to their student's personality in the daily life.

According to Sagala (2000) said that there are ten of teacher's competences. They are: (1) acquire the basic of education, (2) acquire the material, (3) the ability to manage the program, (4) the ability to manage the class, (5) the ability to manage teaching learning interaction, (6) the ability to give the score, (7) the ability to know and translate the curriculum, (8) knowing the function and program of guidance and socialization, (9) understanding principle of teaching and the result, and (10) knowing and conducting educational administration.

Based on the discussion above can be concluded that every teachers due to have personality competence and social competence to be figured by their students. Including at the State of Vocational High School 1 in Lubuk Basung has strong attentions to their teachers to have personality competence and social competence that need by their students in the process of personality building and high social sense.

Kunandar (2007) said that student competence is: "Set of ability that teachers had in order to produce appropriate and efficient work, those are: first, intellectual competence, it is set of knowledge in the individuality that needed to enhance all of the aspect of teacher's job. Second, physical competence, it is set of physical ability that needed to enhance teacher's job in all situation. Third, individual competence, it is set of attitude related with the individual ability to produce teachers ability self autonomous to do their transformation, identity, and self understanding. Fourth, social competence, it is set of certain attitude which became basic self understanding and it took a part from the social environment and also reached of effective social interaction. Fifth, spiritual competence it is understand, comprehending, and experience of spiritual norms".

According to the observation and the appearance had found at the State of Vocational High School 6 in Padang municipalities, teacher's competence was still less to the student's, society and their parents. This competence can be seen by phenomenons related to the individual competences below: (1) Based on students said that a view teacher was still having unstable emotion, it can be seen by seeing its teacher easy to angry when facing naughty students or having a trouble. (2) Lack of keeping stable emotion from teacher to the disturbing stimuli that attacked its feeling, it can cause the school relation running bad. (3) Lack of attitude from the teacher to show a good example to its students, it can cause the students 
appreciation to their teacher. (4) Lack of communication from the teacher to its students including in teaching learning process and out of it, it can cause the harmonious situation in the school. (5) Lack of carrying and participation of the teacher to student's parent, so it can cause the relation from the teacher to the student's parent not running well.

According to the phenomenons above, those describe that there are factors affected to the lack of teacher's discipline at State of Vocational High School 6 in Padang Municipality, that is why it needs to push to enhance the achievement of its school organization. The researcher assumed that each of factors that affected to the lack of teacher's discipline is the headmaster's personality competence.

The government's law number 3, years 2007, about the headmaster's competence said that requirement of professionalism of teacher and head master is minimally have DIV/S-1 degree, acquired personal competence, managerial competence, entrepreneurship competence, supervision competence, and social competence. One of them should be acquired by the headmaster is personal competence. Every headmaster should be acquired available personal competence. The personality of headmaster takes an important role to the goal of education, especially in teaching learning process. Teacher's personality is also took an important role in the student's personality building.

Personality competence takes an important role in the development of student's personality (Ulya, A. 2010; Mizal, B. 2014). Kunandar (2010) said that "personal competence is the ability of teacher which shows well personality, stable, mature, skillful, power, became a model to its students and having wise attitude". These competences take an important role and its function in both of teacher and students personality building to prepare and enhance human resources and the prosperity of society, national development, and nation as far (Chumaedi, A. 2012; Alfian, A. A. 2013; Sleman, M. T. K., \& Kalijaga, F. T. U. S 2009). The lack of headmaster's personal competences in the field of research which can be observed, as bellow: (1) the frequently of headmaster's come late. It showed by coming to the school 08.00 a.m. whereas the normal time was at 07.00 a.m. (2) sometimes the headmaster was busy with the personal activities in the effective time.

Based on the phenomenon above related with the headmaster's personality do not conducive with the headmaster's leadership. This case that headmaster does not give a model anymore to its subordinate. It also brings unstable condition to the development and enhancement of school program, which is also affected to the level of whole of school achievement.

According to those phenomenon the researcher interested to conduct the research and discuss it on the title: "The contribution of headmaster's personality competence to the teacher's social competence of Vocational High School".

\section{Method}

This research is designed by correlation research (Moring, B.,2014; Slavin, R. E., 1992). The aimed of the research is to know the contribution of headmaster's personal competence to the social teacher's competence at State of Vocational High School 6 in Padang Municipality. The populations in this research are teachers from State of Vocational High School in Padang, totality of the population are 68 teachers. Technique sample used is stratified random sampling whereas in this technique is available to heterogeneous population consisted with various group, lining or proportional level which only through simply random and systematic possibility to be chosen to group sample or certain level only (Iskandar, 2009). In accordance to 68 teachers as the population will take the sample around 55 teachers. Furthermore, the instrument used in this research is test validity instrument and reliability test instrument. Data analysis used in the research is correlation (Wherry, R. J. 2014; Sugiono, 2014; Rose-Smith, C. 2012).

\section{Results and Discussions}

\section{Research Data Description}

Related with the variables of the research, so this research got two groups of data, they are the data from headmaster's personality competence of and teacher's social competence from the State of Vocational High School 6 in Padang Municipality. The description of each data can be specified as bellow:

The contribution of headmaster's personality competence to the teacher's social competence ... | 27 Indonesian Counselor Association (IKI) | DOI: 10.23916/002017027710 


\section{The Headmaster's personality competence}

Collecting the data from headmaster's personal competence (X variable) got from distributing of questionnaire to 73 respondents. The variable score of headmaster's personal competence from distributing of questionnaire was 91,00 in lower score until 125,00 as the higher score. Beside that minimal score was 25 and maximal scoring ideally in 125. Based on the result of tabulation, so the score of headmaster's personal competence on the average (mean) 107,75 , median $=106$, modus $=102,5$, and standard deviation $(S D)=8,8$. Furthermore the score of frequency distribution and histogram can be seen on the table below:

Table. 1

Frequency distribution score of headmaster's personal competence of the state vocational high school 6 in Padang municipality

\begin{tabular}{ccc}
\hline Interval Class & Absolute Frequency & Relative Frequency \\
\hline $91-95$ & 8 & $10,95 \%$ \\
$96-100$ & 10 & $13,7 \%$ \\
$101-105$ & 11 & $15,06 \%$ \\
$106-110$ & 15 & $20,54 \%$ \\
$111-115$ & 13 & $17,80 \%$ \\
$116-120$ & 10 & $13,7 \%$ \\
$121-125$ & 6 & $8,21 \%$ \\
Total & 73 & $100 \%$ \\
\hline
\end{tabular}

Frequency distribution score of headmaster's personality competence of the State of Vocational High Shcool 6 Padang Municipality variable can be explained on the picture bellow:

Picture. 1

Histogram of frequency distribution score of headmaster's personality competence variable

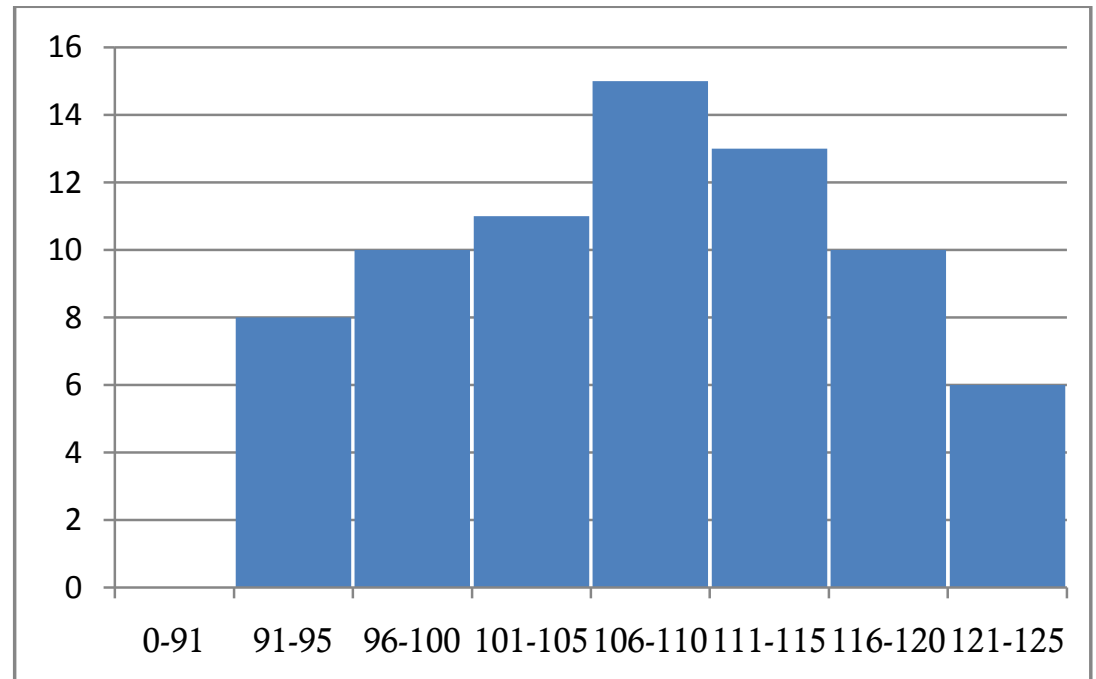

Based on the table and histogram above, it can be seen that $20,54 \%$ from headmaster's personality competence score existed on the average interval class 15 persons, $17,80 \%$ from the headmaster's personality competence score existed on the top interval class around 13 persons. $15,06 \%$ from the headmaster's personal competence score existed on the low of interval class around 11 persons. Furthermore around 34 persons declared that headmaster's personal competence score existed on the low of average with percentage $46,56 \%$. 


\section{Teacher's Social Competence}

Result of processing data to work discipline had shown that maximal score was 150 , minimal score was 30 , the higher score was 145 , the lower score was 111 , mean (average) $=127,46$, median $=126$, modus $=$ 123, 08 and standard deviation score was 9,3.

Table. 2

Frequency distribution score of teacher's social competence at the state of vocational high school 6 in Padang municipality

\begin{tabular}{cccc}
\hline No & Interval Class & Absolute Frequency & Relative Frequency \\
\hline $\mathbf{1}$ & $111-115$ & 9 & $12,32 \%$ \\
$\mathbf{2}$ & $116-120$ & 10 & $13,70 \%$ \\
$\mathbf{3}$ & $121-125$ & 13 & $17,80 \%$ \\
$\mathbf{4}$ & $126-130$ & 15 & $20,54 \%$ \\
$\mathbf{5}$ & $131-135$ & 9 & $12,32 \%$ \\
$\mathbf{6}$ & $136-140$ & 8 & $10,95 \%$ \\
$\mathbf{7}$ & $141-145$ & 9 & $12,32 \%$ \\
Total & & 73 & $100 \%$
\end{tabular}

Frequency distribution score of variable of teacher's social competence at the State of Vocational High School 6 in Padang can be explained as bellow:

Picture 2

Histogram Frequency Distribution Score of Teacher's Social Competence at the State of Vocational High School 6 in Padang Municipality

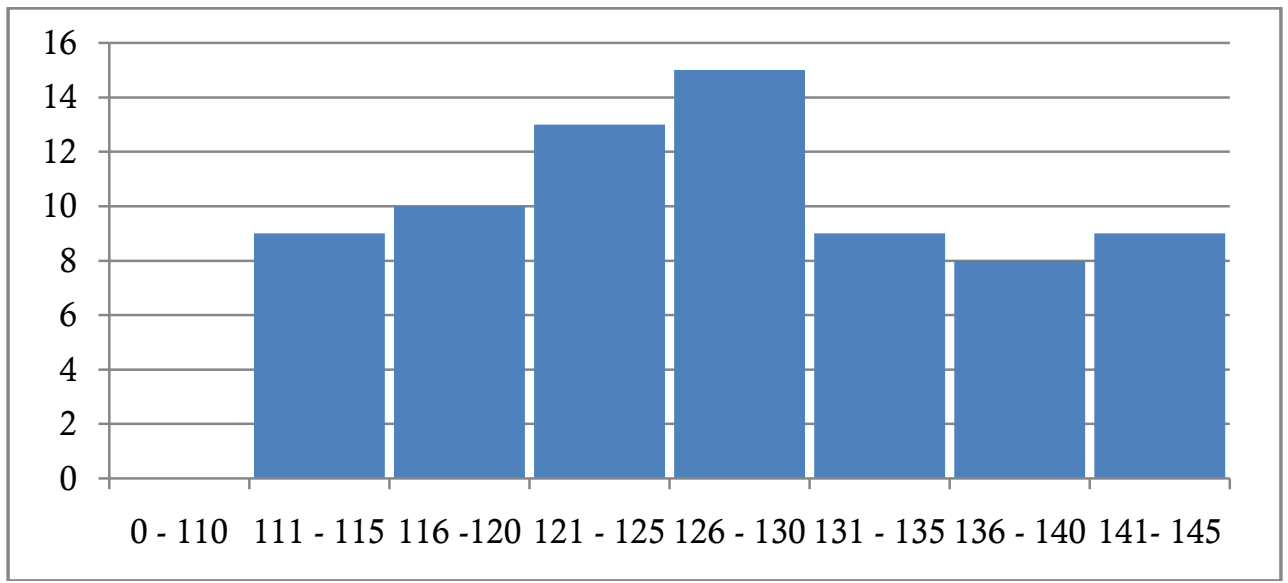

Based on the histogram and Table above shown that there is $20,54 \%$ from the social teacher's competence existed in average interval class 15 persons, $25,59 \%$ from the social teacher's competence score existed in the interval class 26 persons, and $43,82 \%$ from the social teacher's competence score existed in the low of interval class around 32 persons. 


\section{Analysis regulation test}

Hypothesis testing in this research conducted with the correlation technique. It is used to know the relation between $\mathrm{X}$ variable and $\mathrm{Y}$ variable that must be filled a certain requirement, that is normality test and linearity test. Normality test conducted with chi quadrate technique to $\mathrm{X}$ variable of headmaster's personal competence and Y variable, teacher's social competence of the State of Vocational High School 6 in Padang Municipality bellow is the table of normality testing result to both variables of the research:

Table 3

Summary of Normality Testing Variable

\begin{tabular}{cccc}
\hline Variable & $\mathbf{X}^{2}$ & Description & $\mathbf{X}^{2}$ table \\
\hline & & & $\alpha=0,05$ \\
Headmaster's Personality Competence & 5,96 & Normal & 9,488 \\
Teacher's Personal Competence & 4,171 & Normal & 9,488 \\
\hline
\end{tabular}

Result on the table above shows that $\mathrm{X}$ variable of headmaster's personality competence, the score of $\mathrm{X}^{2}$ account 5,96 is smaller than $\mathrm{X}^{2}$ table 9,488 . It is also with the $\mathrm{Y}$ variable of teacher's social competence, the score of $\mathrm{X}^{2}$ account 4,171 is smaller than score of $\mathrm{X}^{2}$ table on significant score 0,05 . So, it can be concluded that both data of variables has a normal distribution.

\section{Hypothesis Testing}

In order to get the image of contribution between variables of the research, so the first step that researcher done is determined the relation and meaning of both variable of the research. The statistic technique used is correlation technique and t- Test. The summary of the result of correlation test and correlation meaning between both variables of the research can be seen on the table below:

Table 4

Result of Correlation Coefficient Testing and Correlation Meaning Variable X and Y with r-Test Table and t-Test Table

\begin{tabular}{cccc}
\hline $\begin{array}{c}\text { Correlation } \\
\text { Coefficient }\end{array}$ & $\mathbf{r}_{\text {table }}$ & Correlation Meaning (t) & $\mathbf{t}_{\text {table }}$ \\
\hline $\mathbf{( r )}$ & $\alpha=0,05$ & & $\alpha=0,05$ \\
$\mathbf{0 , 3 6}$ & 0,207 & 3,25 & 2,776 \\
\hline
\end{tabular}

A counting result on the table had above shown that correlation coefficient between headmaster's personality competence with the teacher's social competence was significant in $r_{\text {count }}=0,036>r_{\text {table }}=$ 0,207 in the credibility level $95 \%$. To know the relational meaning did by conducting t- Test with the data score $t_{\text {count }}=3,25>t_{\text {table }}=2,776$ in the credibility level $95 \%$, it means that the hypothesis of there is a significant relation between headmaster's personality competence with the teacher's social competence can be accepted. So it can be concluded that there is significant correlation between headmaster's personality competences with the teacher's social competence at the State of Vocational High School 6 in Padang.

Furthermore, the level of headmaster's personality competence variable $(\mathrm{X})$ to teacher's social competence can be found by counting quadrate score from the coefficient correlation $\mathrm{Rxy}^{2}$. So, the level of contribution $\mathrm{X}$ variable and $\mathrm{Y}$ variable is about $\left(0,36^{2^{*}} 100 \%=12,96 \%\right)$. According to this information can be concluded that contribution variable of headmaster's personality competence of the State of Vocational High Scholl 6 to the teacher's social competence at the State of Vocational High Scholl 6 is about 12,96\%. 


\section{Result Discussion}

Based on the result of the research at the State of Vocational High Scholl 6 in Padang Municipality, found that there is significant correlation between headmaster's personality competence with the teacher's discipline work at the significant level $95 \%$ with coefficient correlation 0,36 and correlation meaning 3,25 through $\mathrm{t}$ - test. Bellow was the discussion of each variables:

\section{Social Competence variable $(\mathrm{Y})$}

According to result of the research at the State of Vocational High Scholl 6 in Padang Municipality about the correlation of headmaster's personality competence with the teacher's discipline work got the data of teacher's discipline work existed in well categorize $84,97 \%$ with comparing the average score (mean) with the higher score multiple by 100\%. It meant that Teacher's social competence at the State of Vocational High Scholl 6 in Padang Municipality is well.

Sondang said (2011) discipline is the act of management to push management organization members filling the demand of any other of its requirements. Every organization needs various demands which should be followed by its members and having standard required fulfillment (Gunasekaran, A. 1998). Malayu (2009) argued that a good discipline work figured responsibility of people to its job.

According to result of the research shown that teacher's discipline work at the State of Vocational High Scholl 6 in Padang Municipality, generally exited in well categorize. If it tried to look over on the indicator of teacher's discipline work, so the lower indicator was the responsibility indicator, it was on the average 4,1 . It caused by the officer that holded the non available work with its ability, that is why the discipline work needed a responsibility of people to follow all of the rules without existing of an effective any other things, so that it is needed high of responsibility to its work. So, by its high of responsibility, the work will be done well and brought the maximal product achievement.

Personal Competence Variable (X)

Based on the data gotten from respondents which meant by comparing average score (mean) with higher level score multiplied by $100 \%$ can be known the scoring of headmaster's personality competence was on well categorize $(86,2 \%$ from ideal score). Personality is whole of individuality that consist with the mental and physical element from the whole of attitude performance of people through awareness (Fahrudin and Ali, 2011). From the result of the research researcher found that variable of headmaster's personality competence at the State of Vocational High Scholl 6 in Padang Municipality, commonly existing in well categorize.

If it tried to look in personality competence indicator, the lower indicator was having trace and interest of position desire indicator as the leader of education with the average 4,0. It caused by the lack of available soul of leader from the headmaster related with school's needed. That is why the headmaster should be having the trace of position to be effective headmaster (Halliger, P., Bickman, L., \& Davis, K. 1996). Beside that the headmaster's personal competence figured personal steady, stable, mature, wise, and authority, became a model and also wise character. The effort to increase the trace and interest as the headmaster is having trace position to be effective headmaster, having soul of leader which is available with the school needed (Chapman, J. D., \& International Institute for Education Planning, 2005).

\section{The Contribution of Headmaster's Personal Competence to the Teacher's Social Competence}

Result of testing hypothesis shown that there is a significant meaning between headmaster's personality competence with teacher's social competence, through $r_{\text {count }}=0,36>r_{\text {table }}=0,207$ on the level of credibility 95\%. It meant that there is significant relation between personality competence with teacher's social competence at the State of Vocational High Scholl 6 in Padang Municipality, the score of the result of testing significance relation was $t_{\text {count }}=3,25>t_{\text {table }}=2,776$ on the level of credibility $95 \%$. So, according to this information there is significant relation between headmaster's personality competence to the teacher's social competence at the State of Vocational High Scholl 6 in Padang Municipality.

It is also informed that each of factors affected to the teacher's social is headmaster's personality competence. It is related with the Malayu (2010) argued that a good leader is a person who gives a good model, having a good discipline, honest, fair, and suit between spoken and action. Through good 


\section{COUNS-EDU}

Vol. 2, No.1, March 2017

Available online: http://journal.konselor.or.id/index.php/counsedu

Nellitawati ,N

personality leading will produce good teacher's social competence (Berkowitz, M. W., \& Bier, M. C. 2004; Fullan, M. 2011), but in contrast with this, a bad personality leading will produce lack of teacher's personality in associate to school environment. Furthermore, by using coefficient correlation $r_{\text {count }}=0,36>$ $\mathrm{r}_{\text {table }}=0,207$, on the level of credibility $95 \%$ gotten score of headmaster's personality competence to the teacher's social competence on the score $12,96 \%$. It means that teacher's social competence at the State of Vocational High Scholl 6 in Padang Municipality determined by the headmaster's personality competence, remainder determined by others factor which affected, whether in direct or not that do not discuss in this research.

\section{Conclusions}

According to result of the research and hypothesis testing about relation headmaster's personality competence with the teacher's social competence at the State of Vocational High Scholl 6 in Padang Municipality can be concluded like this one: (1) headmaster's, teacher's personality competence at the State of Vocational High Scholl 6 in Padang Municipality is good, with the level of achievement score $86,2 \%$. (2) Teacher's social competence at the State of Vocational High Scholl 6 in Padang Municipality is also existed in a good categorize, with the level of achievement score $84,97 \%$. (3) There is a significant relation between headmaster's personality competence with the teacher's social competence at the State of Vocational High Scholl 6 in Padang Municipality with the coefficient correlation $r_{\text {count }}=0,36>r_{\text {table }}=$ 0,207 on the level of credibility $95 \%$. The level contribution of headmaster's personality competence is relatively insignificant to the teacher's social competence at the State of Vocational High Scholl 6 in Padang. It means that headmaster's personality competence gives a contribution to the teacher's social competence at the State of Vocational High Scholl 6 in Padang Municipality around 12,96\%.

Accordingly, it can be suggested as bellow: (1) It is hoped for the headmaster's of the State of Vocational High Scholl 6 in Padang Municipality to increase its personality competence, such as wise attitude, integrity, having a strong desire on self development, fair, controlling himself when meeting with the work problem, having trace and interest of position as the education leader. Because, a good personality of leader will bring teacher's discipline work too, (2) It is hoped to the teacher of the State of Vocational High Scholl 6 in Padang Municipality became an input or information in the development of teacher's social competence at the State of Vocational High Scholl 6 in Padang Municipality. That is why, teacher may do various of effort, such as on time, awareness, loyalty and responsibility in doing work in order to increase its work's discipline, (3) it is hoped to supervisor to enhance the supervision in order to make headmaster and teacher always be improved their competency especially headmaster's personality of headmaster and teacher's social competence, whereby it can be improved the harmonious relation between the headmaster as the leader to the teacher as the educator, (4) The writer, to add the insight and knowledge about the relation of Headmaster's Personality Competence with the teacher's social competence as well as applied the knowledge gotten during lecturing process.

\section{Acknowledgments}

We would like to thank Universitas Negeri Padang for the Grant. Finally, we express much gratitude to all students who participated on this research.

\section{References}

Adiputra, I. N., Sugihartini, N., Wahyuni, D. S., \& Sunarya, I. M. G. (2014). Pengembangan E-Modul pada Materi "Melakukan Instalasi Sistem Operasi Jaringan Berbasis GUI dan Text" untuk Siswa Kelas X Teknik Komputer dan Jaringan SMK Negeri 3 Singaraja.

Alfian, A. A. (2013). Upaya Guru Pendidikan Agama Islam dalam Meminimalisir Kekerasan Siswa Melalui Program Pembiasaan di kelas VIII SMP Negeri 2 Sewon Bantul (Doctoral dissertation, UIN Sunan Kalijaga).

Ariansyah, B. (2016). Hubungan Kompetensi Sosial Guru Terhadap Motivasi EKSTRINSIK Siswa di MTS ALIttifaqiah Indralaya Ogan ILIR.(Skripsi) (Doctoral dissertation, UIN Raden Fatah Palembang). 
Ariyanti S, H. E. N. Y. (2008). Peningkatan Hasil Belajar Biologi Pokok Bahasan Sistem Peredaran Darah Dengan Model Pembelajaran Tipe Think-Pair-Share Pada Siswa Kelas VIII C SMP Muhammadiyah 7 Surakarta Tahun Ajaran 2007/2008 (Doctoral dissertation, Universitas Muhammadiyah Surakarta).

Arnawa, I. K. (2012). Determinasi Latihan Kerja, Kompetensi Kewirausahaan dan Bimbingan Karier terhadap Kesiapan Kerja Siswa Smk Negeri Kelompok Teknologi Dan Rekayasa di Kabupaten Buleleng. Jurnal Administrasi Pendidikan, 3(2).

Avalos, B. (2011). Teacher professional development in Teaching and Teacher Education over ten years. Teaching and teacher education, 27(1), 10-20.

Berkowitz, M. W., \& Bier, M. C. (2004). Research-based character education. The Annals of the American Academy of Political and Social Science, 591(1), 72-85.

Chapman, J. D., \& International Institute for Educational Planning. (2005). Recruitment, retention, and development of school principals. International Institute for Educational Planning.

Chumaedi, A. (2012). Hubungan Kompetensi Pedagogik Guru Dengan Motivasi Belajar Siswa Kelas X Pada Mata Pelajaran Tarikh di SMA Muhammadiyah Sewon Bantul Yogkyakarta (Doctoral dissertation, Perpustakaan UIN Sunan Kalijaga).

Departemen Pendidikan Nasional. (2005). Undang-Undang Nomor 14 Tahun 2005. Tentang Guru dan Dosen. Jakarta: Depdiknas.

Depdiknas. (2007). Peraturan Menteri Pendidikan Nasional Republik Indonesia Nomor 13 tahun 2007 tentang Standar Kepala Sekolah/Madrasah. Jakarta: Depdiknas.

Fachruddin Dan Ali. (2011). Pengembangan Profesionalitas Guru. Jakarta: Gaung Persada.

Fitriani, L. (2012). Kecerdasan Emosional Pada Guru Taman Kanak-kanak (Studi Deskriptif).

Fullan, M. (2011). The six secrets of change: What the best leaders do to help their organizations survive and thrive. John Wiley \& Sons.

Gunasekaran, A. (1998). Agile manufacturing: enablers and an implementation framework. International Journal of Production Research, 36(5), 1223-1247.

Hallinger, P., Bickman, L., \& Davis, K. (1996). School context, principal leadership, and student reading achievement. The Elementary School Journal, 96(5), 527-549.

Indonesia, P. R. (2003). Undang-Undang Republik Indonesia Nomor 20 Tahun 2003 Tentang Sistem Pendidikan Nasional.

Indriyanti, N., \& Ivada, E. (2013). Faktor-Faktor Yang Memengaruhi Minat Melanjutkan Pendidikan Ke Perguruan Tinggi Pada Siswa Kelas Xii Akuntansi Smk Negeri 6 Surakarta Tahun 2013. Jupe-Jurnal Pendidikan Ekonomi, 1(2).

Iskandar. (2009). Metodologi Penenlitian Pendidikan dan Sosial. Jakarta: Gaung.

Kunandar. (2010). Guru Profesional. Jakarta: Rajawali Press.

Maghfiroh, A. (2010). Peran kepala sekolah sebagai supervisor dalam peningkatan mutu guru PAI di SMP Nasima Semarang (Doctoral dissertation, IAIN Walisongo).

Mala, D. K. (2016). Bimbingan Guru (PAI) dalam Membina Akhlak Peserta Didik di MTs Negeri Aryojeding Tahun Ajaran 2015/2016.

Malayu, S. P. Hasibuan. 2009. Manajemen Sumberdaya Manusia. Jakarta: Bumi Aksara.

Masyruroh, N. (2010). Pengaruh Kompetensi Kepribadian Guru PAI Terhadap Kegiatan Belajar Mengajar PAI di UPTD SMP Negeri 1 Sumbergempol, Tulungagung.

Mizal, B. (2014). Pendidikan dalam Keluarga. Dalam Jurnal Ilmiah Peuradeun, 2(3).

Moring, B. (2014). Research methods in psychology: Evaluating a world of information. WW Norton \& Company.

Munawaroh, D. (2014). Kompetensi Sosial Guru Pai Dan Relevansinya Dengan Pembentukan Karakter Siswa di SMK Negeri 1 Nglipar Gunungkidul (Doctoral dissertation, UIN Sunan Kalijaga).

Muspiroh, N. (2016). Peran Kompetensi Sosial Guru dalam Menciptakan Efektifitas Pembelajaran. Edueksos: Jurnal Pendidikan Sosial \& Ekonomi, 4(2). 


\section{COUNS-EDU}

Vol. 2, No.1, March 2017

Available online: http://journal.konselor.or.id/index.php/counsedu

Nellitawati ,N

Muspiroh, N. (2016). Peran Kompetensi Sosial Guru dalam Menciptakan Efektifitas Pembelajaran. Edueksos: Jurnal Pendidikan Sosial \& Ekonomi.

Purnomo, E., \& Munadi, S. (2005). Evaluasi Hasil Belajar dalam Implementasi Kurikulum Berbasis Kompetensi di Sekolah Menengah Kejuruan. Jurnal Cakrawala Pendidikan, (2).

Putri, N. A. (2011). Penanaman Nilai-Nilai Pendidikan Karakter Melalui Mata Pelajaran Sosiologi. Komunitas: International Journal Of Indonesian Society and Culture, 3(2).

Rose-Smith, C. (2012). A correlational analysis of leadership traits and styles of emergency managers related to effective emergency management. Walden University.

Sagala,Syaiful. (2011). Kemampuan Professional Guru Dan Tenaga Kependidikan. Bandung: Alfabeta.

Sharples, M. (2002). Disruptive devices: mobile technology for conversational learning. International Journal of Continuing Engineering Education and Life Long Learning, 12(5-6), 504-520.

Slavin, R. E. (1992). Research methods in education. Allyn \& Bacon.

Sleman, M. T. K., \& Kalijaga, F. T. U. S. (2009). Upaya Musyawarah Guru Mata Pelajaran (MGMP) Fiqih Kabupaten Sleman dalam Peningkatan Profesionalisme Guru Fiqih.

Sondang P. Siagian. (2011). Manajemen Sumber Daya Manusia. Jakarta: Bumi Aksara.

Sugiyono. (2014). Metode Penelitian Kuantitatif, Kualitatif, dan Kombinasi (Mixed Methods). Bandung: Alfabeta.

Surya, H. (2010). Jadilah pribadi yang Unggul. Elex Media Komputindo.

Syaikhul Alim, M. (2010). Pengaruh Kualifikasi Pendidikan, Keikutsertaan Diklat dan Sikap pada Profesi terhadap Kompetensi Guru PAI SD di Kabupaten Pekalongan (Doctoral dissertation, IAIN Walisongo).

Ulya, A. (2010). Strategi kepala sekolah dalam peningkatan mutu tenaga pendidik di SDI Hidayatullah Semarang (Doctoral dissertation, IAIN Walisongo).

Wherry, R. J. (2014). Contributions to correlational analysis. Academic Press.

Wong, J. K. K. (2004). Are the Learning Styles of Asian International Students Culturally or Contextually Based?. International Education Journal, 4(4), 154-166.

Yasin, M., \& Ansori, A. (2014). Pengembangan Modul Transmisi Otomotif Mobil Untuk Meningkatkan Kualitas Hasil Belajar Siswa Kelas XII di Sekolah Menengah Kejuruan. Surabaya: Universitas Negeri Surabaya.

Yuni, R. (2015). Kompetensi Pedagogik Guru Sekolah Dasar Se Kecamatan Kretek Kabupaten Bantul (Doctoral dissertation, Universitas Negeri Yogyakarta).

Yuniarti, Y., Harsono, N., \& Istianti, T. (2015). Penggunaan Model Brainstorming untuk Meningkatkan Kreativitas Berpendapat Siswa dalam Pembelajaran IPS di Sekolah Dasar. Jurnal PGSD Kampus Cibiru, $3(2)$. 